\title{
Basal carcinoma of the breast revisited: an old entity with new interpretations
}

\author{
E Korsching, ${ }^{1}$ S S Jeffrey, ${ }^{2}$ W Meinerz, ${ }^{4}$ T Decker, ${ }^{1}$ W Boecker, ${ }^{1}$ H Buerger ${ }^{3}$
}

${ }^{1}$ Institute of Pathology, University of Muenster, Germany; ${ }^{2}$ Department of Surgery, Stanford University School of Medicine, Stanford, California, USA; ${ }^{3}$ Institute of Pathology, Cooperative Breast Center, Paderborn, Germany;

${ }^{4}$ Department of Gynecology, Cooperative Breast Center, St Vinzenz-Hospital, Paderborn, Germany

Correspondence to: Professor H Buerger, Institute of Pathology, Husener Str. 46a, 33098 Paderborn, Germany; buerger@histopatho.eu

Accepted 14 February 2008 Published Online First

6 March 2008

\section{ABSTRACT}

The introduction of global gene expression analysis in breast cancer research has focused attention onto a repeatedly described subgroup of invasive breast cancer, the basal-like carcinomas. This subgroup is characterised by the expression of high-molecular weight cytokeratins 5 , 14 and 17; using immunohistochemical diagnosis, it represents approximately $7-20 \%$ of invasive breast cancers. Some of these tumours fulfil the criteria of grade 3 invasive ductal carcinoma, the so-called triple negative carcinomas. However, other rare subgroups of metaplastic, medullary and myoepithelial carcinomas also belong to this entity. Even though the initial clinical prognostic relevance of basal-like breast cancers may have been overestimated, its distinctive biology generates many questions regarding the pathogenesis, chemosensitivity and optimal clinical management of this subgroup. Physiological progenitor cells within the normal female breast share essential immunohistochemical features with basal-like breast cancers. Although the exact relationship between subgroups of normal breast cells and their respective malignant counterparts is still under investigation, the major hallmarks of physiological progenitor cells are either maintained or reactivated by distinct genetic changes in basal breast cancer cells. This review will discuss the impact of these findings on our global understanding of breast cancer pathogenesis, especially from the perspective of its potential histogenesis. Clinical consequences and potential future research directions driven by the definition of basal breast cancers will also be discussed.

\section{CLASSIFICATION OF BREAST CANCER ACCORDING TO GENOTYPE AND IMMUNOPHENOTYPE}

The classification of invasive breast cancer for surgical, prognostic and predictive purposes is part of the basic workup of every breast cancer specimen, and usually involves molecular and immunohistochemical assays. ${ }^{1}$ These conventional, mainly morphology-based approaches have been clinically validated and serve as the gold-standard for prognosticating patient outcome. Other molecular markers, such as the oestrogen receptor (ER), progesterone receptor (PR), and expression of the growth factor receptor HER2, provide therapeutic predictive value, and are of central importance for the clinical management of breast cancer. However, many other genes have limited clinical value, and the subclassification of breast cancers based on the expression of these single genes offers incomplete prognostic and predictive information. Thus, investigators are continually searching for new breast cancer biomarkers, especially those that predict therapeutic efficacy of conventional and molecular-based chemotherapeutic treatments.

Novel classification systems based on the definition of cytogenetic alteration patterns have given rise to the postulation of multiple, parallel pathogenetic pathways in breast cancer. ${ }^{2}{ }^{3}$ For example, the distribution of 16q-losses in different grades of breast cancers shows that invasive breast cancer is comprised of multiple distinct subgroups that do not necessarily arise from sequential genetic and morphological dedifferentiation steps. ${ }^{4}$ Global gene expression profiling using microarray analysis extended our current knowledge and promises to further improve predictive and prognostic power in breast cancer pathology. Gene expression studies have used different microarray platforms to address slightly different questions. One research approach used supervised classification techniques to define gene sets for prognostic purposes, identifying genes that were differentially expressed in patients who, within a finite period of time, did and did not develop metastatic disease (e.g. "prognostic 70-gene set" $\left.{ }^{\prime \prime}\right)$. Others used different methods to determine gene signatures that would classify breast cancers into distinct molecular subtypes (the Stanford/Norway "intrinsic" gene set $\left.^{7-9}\right)$. The first approach was further refined by associating the "prognostic 70-gene set" with a "core serum response" gene set-considered representative of wound healing processes - to generate a better predictor of clinical outcome in patients with earlier stage breast cancer. ${ }^{10}$ Classification of breast cancer using the "intrinsic" gene set defined by Perou and colleagues has stimulated recent intense interest in the pathophysiology and best treatments for diverse tumour subtypes. However, it has also generated confusion regarding appropriate subtype nomenclature.

Two decades ago, Dairkee et al described a small subgroup of breast cancers that, similar to cells from normal basal epithelium, exclusively expressed a high molecular weight basal cytokeratin, and that had poor prognostic characteristics, postulating that these cancers may originate in "basally located precursor cells often referred to as 'stem cells' and may represent tumours of the undifferentiated stem cell". ${ }^{11}$ A more recent study ${ }^{12}$ analysed a group of 295 breast cancers using five diverse gene expression signature sets, including classification gene sets and prognostic gene sets; despite each signature set containing different genes, there was good concordance of patientspecific outcome predictions for the majority of the breast cancer patients. In other words, individual tumours appear to have a good or bad prognostic phenotype, regardless of the gene set used to define 
A

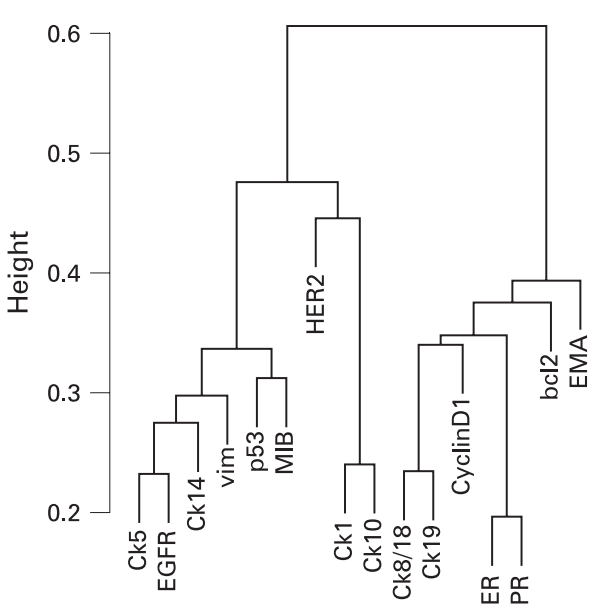

C

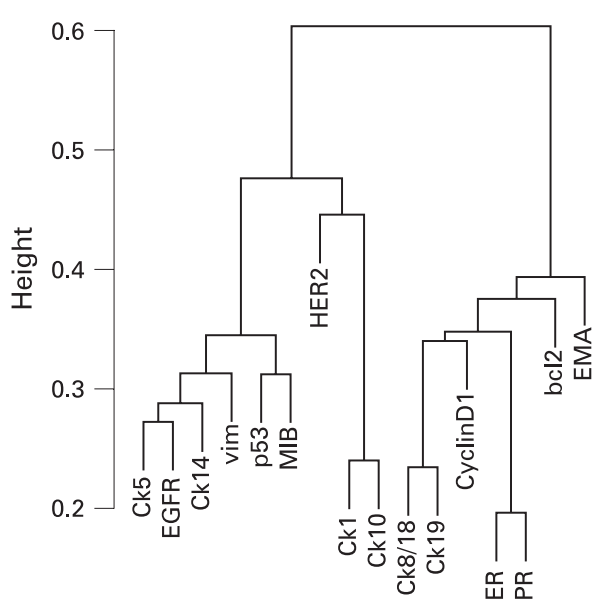

B

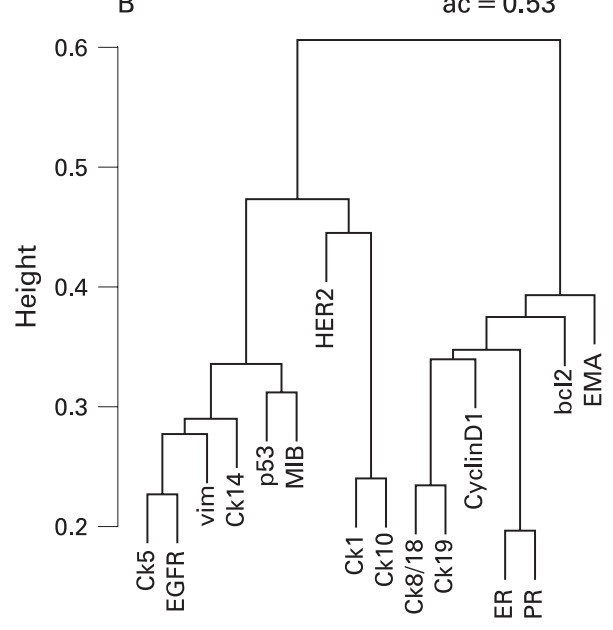

D

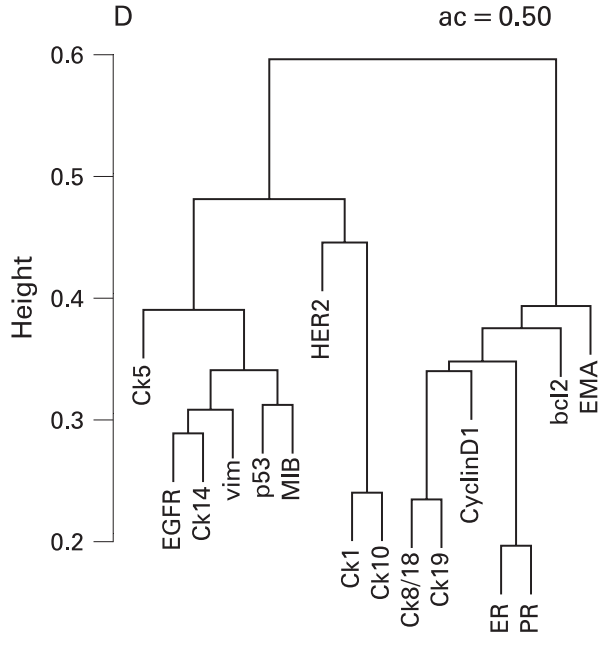

Figure 1 Cluster analysis of 527 invasive breast cancers according to their immunohistochemical expression profile. The methods, including the source, dilution and pretreatment for the respective antibodies have been published previously. ${ }^{35}$ Missing immunohistochemical data ( $9 \%$ of all data) were replaced by the median of that specific score. Hierarchical cluster analysis (method: average linkage, agglomerative coefficient (ac, cluster quality measure) from 0 [poor] to 1 [good]) based on the correlation was applied. Evaluations were performed with the statistical platform S-Plus V.6.r2 using the function "agnes" based on published algorithms. The results were visualised in a dendrogram showing graphically the similarity of the vectors with the respective immunohistochemical observations. Four different quantification schemes for the expression rates of Ck 5 were analysed $[(A)$ is based on all score levels; $(B)$ to $(D)$ are derivatives of $(A)]$. (A) Four levels: negative, weak positive $(>10 \%)$, positive $(>25 \%)$ and strong positive ( $>50 \%$ tumour cells); (B) Two levels: threshold $10 \%$ (negative level // all positive levels). (C) Two levels: threshold $25 \%$ (negative + weak positive level // positive + strong positive level). (D) Two levels: threshold 50\% (negative + weak positive + positive level // strong positive level). It is noteworthy that the different thresholds have hardly any influence on the cluster analysis, indicating that no definite threshold defines the "basalness" of breast carcinomas.

that phenotype. This means that multiple feature patterns can define and distinguish specific tumour subtypes, but no one pattern can adequately explain the causal development of the different phenotypes.

\section{BASAL BREAST CANCER}

Basal cytokeratins (Ck) represent a large number of highmolecular weight (HMW) cytokeratins which, according to the catalogue of human cytokeratin expression, are mainly seen in the basal cell layers of stratified epithelium. ${ }^{13}$ In the human breast, these cytokeratins are also expressed in the basallylocated myoepithelial cell layer and in a small proportion of luminal, glandular cells. ${ }^{14}$ The dual meaning of the term "basal" in the breast induced confusion, as "basalness" was often interpreted as a sign of a myoepithelial origin. ${ }^{15}$ However, as shown below and discussed previously, this explanation might not be sufficient. ${ }^{16}$
A subgroup of invasive breast cancers expressing basal cytokeratins was first described in 1987 and 1996. ${ }^{17}{ }^{18}$ More recent studies have shown that the incidence among Caucasian women ranges around $16 \%$, with significant differences among different ethnic subgroups. ${ }^{19}$ Further studies gave additional insights into the characteristics of this tumour subgroup, such as expression of hyperproliferation-associated cytokeratins and the coexpression of basement membrane material in these tumours. ${ }^{20} 21$ Prior to the description of basal carcinomas by microarray technology, studies pointed to clinical and morphological characteristics, ${ }^{22}$ including the presence of brain metastasis. ${ }^{23}$ However, this tumour group, defined by the expression of $\mathrm{Ck} 5,14$ or 17 is rather heterogeneous. ${ }^{24}$ Recent work studying Ck 5 expression showed that this group is comprised of not only grade 3 invasive ductal carcinomas (NOS), but also other histological breast cancer subgroups, such as metaplastic ${ }^{25}$ and medullary carcinomas, ${ }^{26}$ with or without associated BRCA1 
Table 1 Overview of the design and most important results of studies focusing on the prognostic and/or predictive value of basal cytokeratin expression in invasive breast cancer

\begin{tabular}{|c|c|c|c|c|c|}
\hline Authors & $\begin{array}{l}\text { Source of } \\
\text { tissue }\end{array}$ & Clinical data & $\begin{array}{l}\text { Type of basal } \\
\text { cytokeratin }\end{array}$ & $\begin{array}{l}\text { Threshold for the } \\
\text { expression of basal } \\
\text { cytokeratins }\end{array}$ & Conclusion \\
\hline Rakha et $a l^{51}$ & TMA & Not specified in detail & $\begin{array}{l}\text { Ck } 5 / 6 \text { and/or } \\
\text { Ck } 14\end{array}$ & $10 \%$ & $\begin{array}{l}\text { Expression of } \mathrm{Ck} 5 / 6 \text { and/or } \mathrm{Ck} 14 \text { is sufficient for the } \\
\text { definition of basal breast cancer }\end{array}$ \\
\hline Jumpannen et $a l^{40}$ & TMA & No adjuvant treatment & $\begin{array}{l}\text { Ck } 5 / \text { Ck } 14 / p 63 \\
\text { antibody cocktail }\end{array}$ & $20 \%$ & $\begin{array}{l}\text { No impact on overall survival in ER-negative breast } \\
\text { cancers }\end{array}$ \\
\hline Abd El-Rehim et $a l^{28}$ & TMA & Not specified in detail & $\begin{array}{l}\text { Ck } 5 / 6 \text { and/or } \\
\text { Ck } 14\end{array}$ & Any positive cell & $\begin{array}{l}\text { Expression of basal cytokeratins is an independent } \\
\text { prognostic marker } \\
\text { At least four different immunohistochemical } \\
\text { phenotypes can be defined }\end{array}$ \\
\hline Laakso et $a l^{39}$ & Tissue sections & $\begin{array}{l}\text { (a) without adjuvant } \\
\text { treatment } \\
\text { (b) dose-escalated adjuvant } \\
\text { chemotherapy }\end{array}$ & $\begin{array}{l}\text { Ck } 5 / \text { Ck } 14 / p 63 \\
\text { antibody cocktail }\end{array}$ & $\begin{array}{l}5 \% \\
70 \% \text { for the "true" basal } \\
\text { subtype }\end{array}$ & $\begin{array}{l}\text { The true basal breast cancer subtype in contrast to the } \\
\text { basoluminal subtype is not associated with HER2- } \\
\text { amplifications and showed a significantly different } \\
\text { prognosis } \\
\text { No prognostic value of the expression of basal } \\
\text { cytokeratins in high-risk patients }\end{array}$ \\
\hline Van de Rijn et $a l^{79}$ & TMA & $\begin{array}{l}\text { Patients with and without } \\
\text { adjuvant chemotherapy, and } \\
\text { anti-hormone therapy, } \\
\text { respectively }\end{array}$ & $\begin{array}{l}\text { Ck } 17 \text { and/or } \\
\text { Ck } 5 / 6\end{array}$ & $\begin{array}{l}\text { Invasive tumour cells with } \\
\text { strong staining }\end{array}$ & $\begin{array}{l}\text { Basal cytokeratin expression was an independent } \\
\text { prognostic marker in node-negative breast cancer }\end{array}$ \\
\hline Nielsen et $a l^{45}$ & TMA & $\begin{array}{l}\text { Patients with adjuvant and } \\
\text { neoadjuvant chemotherapy, } \\
\text { anti-hormone therapy, } \\
\text { respectively }\end{array}$ & $\begin{array}{l}\text { Ck } 17 \text { and/or } \\
\text { Ck } 5 / 6\end{array}$ & $\begin{array}{l}\text { Invasive tumour cells with } \\
<20 \% \text { of weak staining }\end{array}$ & $\begin{array}{l}\text { A panel of } 4 \text { antibodies (ER, Ck 5/6, HER2 and EGFR) } \\
\text { can accurately identify basal-like tumours }\end{array}$ \\
\hline Jones et $\left.a\right|^{38}$ & $\begin{array}{l}\text { Tissue sections } \\
\text { of grade } 3 \\
\text { breast cancers }\end{array}$ & Not specified in detail & Ck 14 & Any positive cell & $\begin{array}{l}\text { Basal carcinomas have a decreased overall survival } \\
\text { and show a distinct chromosomal alteration pattern }\end{array}$ \\
\hline Fulford et $a l^{42}$ & $\begin{array}{l}\text { Tissue sections } \\
\text { of grade } 3 \\
\text { breast cancers }\end{array}$ & Not specified in detail & Ck 14 & $\begin{array}{l}\text { At least } 1 \% \text { of invasive } \\
\text { tumour cells }\end{array}$ & $\begin{array}{l}\text { Basal carcinomas develop less bone and liver } \\
\text { metastasis. Overall survival was improved in basal } \\
\text { grade } 3 \text { carcinomas compared to non-basal grade } 3 \\
\text { carcinomas. In metastatic disease the prognosis was } \\
\text { decreased }\end{array}$ \\
\hline Banerjee et $a l^{80}$ & $\begin{array}{l}\text { Tissue sections } \\
\text { of grade } 3 \\
\text { breast cancers }\end{array}$ & Not specified in detail & $\begin{array}{l}\text { Ck } 5 / 6, \text { Ck } 14, \\
\text { Ck } 17\end{array}$ & Any positive cell & $\begin{array}{l}\text { Significantly increased recurrence rate and overall } \\
\text { survival } \\
\text { Adjuvant anthracyline-based chemotherapy seems } \\
\text { less effective compared to grade matched controls }\end{array}$ \\
\hline
\end{tabular}

TMA, tissue microarray.

mutations. ${ }^{27}$ It is noteworthy that the vast majority of these tumours always coexpress a multitude of other cytokeratins. ${ }^{28}$

These tumours also show specific genetic features. In contrast to all other breast cancer subgroups, these tumours, especially the metaplastic subgroup, harbour EGFR-amplifications, ${ }^{29}$ otherwise rarely seen in breast cancer. ${ }^{30}{ }^{31}$ A more recent study characterised an increased expression of genes located on $6 \mathrm{p} 21$ and 12 p13 as hallmarks of medullary carcinomas. ${ }^{32}$ A significant proportion of basal carcinomas are associated with a BRCA1 germ line mutation ${ }^{27}$ or sporadic p53-mutations and/or p53protein overexpression. Compared with $\mathrm{Ck} 5 / 14$ negative breast cancers, a significantly lower rate of $16 q$-losses has been described. ${ }^{34-37}$ However, this significance vanished if the same comparison was made with invasive ductal grade 3 carcinomas only. $^{38}$

In general, the initially described prognostic relevance has now been challenged by various other reports. Although some initial studies evaluated prognosis without consideration of tumour grade, it has since been shown that the prognostic significance of the basal subtype disappears when evaluated alongside other high risk variables in a representative series of breast cancer patients, ${ }^{39}$ in ER-negative, ${ }^{40}$ and in grade 3 breast cancers. ${ }^{41}$ Moreover, a subgroup of basal carcinomas has been associated with an improved prognosis. ${ }^{42}$ More recent gene expression analysis also revealed that a prognostic difference could not be elaborated between the basal and the ER negative/ HER2-overexpressing breast cancer subgroups. ${ }^{12}$ However, the criteria used to define basal breast cancer, as shown below, differ significantly and many accumulated results have this potential bias when compared. Another significant source of bias is that most studies grouped patients together who were undergoing different treatment protocols, again cautioning us not to over-interpret these results. To answer future questions about prognosis and appropriate therapies, controlled prospective clinical trials with uniformly treated patients are mandatory.

\section{MORPHOLOGICAL AND IMMUNOHISTOCHEMICAL CHARACTERISATION OF BASAL BREAST CANCER}

Morphologically, basal carcinomas are mainly grade 3 invasive ductal carcinomas and share a multitude of features definable 
by simple H\&E staining. Tsuda et al were among the first to describe the presence of large, central acellular necrosis as a major hallmark of basal breast cancer. ${ }^{23}$ This was later verified by other groups, who further outlined the presence of central scars and a large degree of peritumoural lymphocytosis, as well as high proliferation rate, presence of spindle cells, and squamous metaplasia. ${ }^{43} 44$

However, there are no currently accepted definitions of "basalness" that use thresholds for distinct HMW-cytokeratins (Ck 5, 14 or 17). This might be partially due to the use of tissue microarrays in many studies, rather than whole tumour tissue sections for immunohistochemical evaluation. Thus, breast carcinomas have been deemed basal when they express HMW-cytokeratin in a single, malignant cell, or in $1 \%, 5 \%$ or $10 \%$ of malignant cells (table 1 ). In addition, one study defined a $50 \%$ threshold for the distinction between basal and basoluminal carcinomas, with the former characterised by the general lack of c-erbB2 (HER2/neu) amplifications. ${ }^{39}$ Despite this general lack of agreement on what defines histological and immunostain "basalness", further immunohistochemical characterisation displayed very similar results in multiple studies. Basal carcinomas have been consistently associated with expression of epidermal growth factor receptor (EGFR), ${ }^{34} 3544$ c-kit, p53, p63, negativity of ER and PR, and, in the initial reports, with lack of HER2-expression. ${ }^{46}$ However, recently the so-called basoluminal carcinomas have been characterised by the expression of Ck 5 and HER2. ${ }^{39}$ Further investigations revealed the coexpression of smooth muscle actin (SMA), CD10 and vimentin in some tumours, ${ }^{47}$ as well as the expression of $\mathrm{P}$ cadherin. ${ }^{48}$ Therefore, even the expression of high molecular cytokeratin in single breast cancer cell might be interpreted as a hint for the presence of a global immunohistochemical expression pattern in the whole tumour. One might therefore argue that "basalness" from an immunohistochemical perspective may be considered an overall tumour cell expression programme, not necessarily defined by the expression of high molecular cytokeratins in the majority of tumour cells. Our own data presented in fig 1 support this assumption: identical gene expression clusters on the protein level could be reproduced irrespective of the set threshold. However, to compare immunohistochemical results with global gene expression profiles requires a direct comparison of both methods within the same tumours. ${ }^{44} 49$

Figure 2 Associations of immunohistochemical expression patterns in physiological cellular subgroups within the normal breast and distinct subgroups of invasive breast cancer.

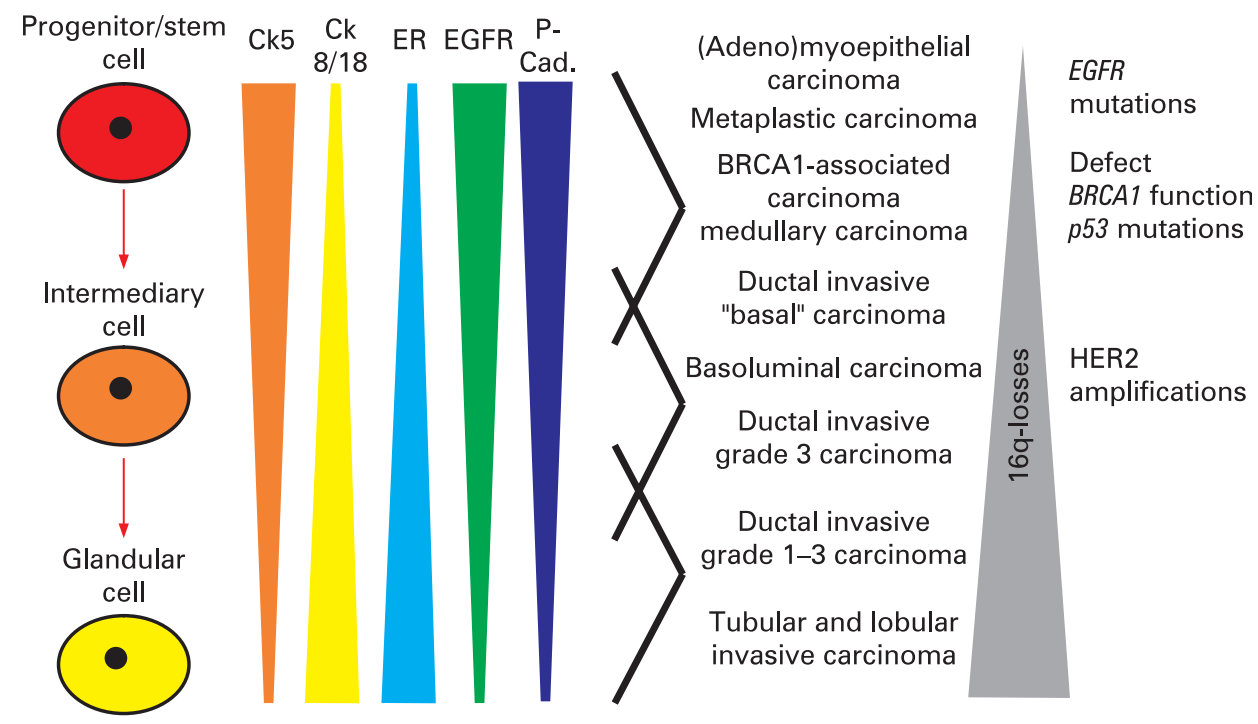

Basal breast cancer requires a set of diagnostic markers, and has been defined differently in different studies. Whereas Nielsen et al defined basal breast cancer as negative for ER and HER2 as well as positive for basal cytokeratins, EGFR and/ or c-kit, ${ }^{45}$ other groups used the combination of negativity for ER and HER2 with positivity for Ck 5 , P-cadherin and $\mathrm{p} 63,{ }^{50}$ or positivity for vimentin, EGFR and $\mathrm{Ck} 5 / 6{ }^{44}$ It may be that, table 1 shows, these different technical approaches in combination with widely differing patient cohorts might explain aspects of the widely differing experimental results for the mentioned markers. Rakha et al showed, in a multivariate analysis, a relationship between the expression of basal cytokeratins and poor prognosis. Interestingly, the addition of other markers as described above did not increase the detection rate of cases with differing outcome compared with the use of basal cytokeratins alone. $^{51}$

\section{BASAL CYTOKERATINS, PHYSIOLOGICAL BREAST PROGENITOR CELLS AND GENETIC ALTERATIONS}

In recent years, basal cytokeratins have been the focus of breast cancer research from another perspective. In 1988, Jarrasch et al discussed the possible existence of $\mathrm{Ck} 5$ positive cells as potential progenitor cells in the female breast that could give rise to the glandular and myoepithelial cell lineage. ${ }^{2}$ However, the data from that time were indirect and derived from simple immunohistochemical experiments. Almost a decade later, studies showed that cells with the potential to differentiate into luminal and myoepithelial cells-one requirement for the definition of progenitor or stem cells-express basal cytokeratins. $^{53}$ Most of these studies were based on mouse or immortalised human mammary cell models. ${ }^{54}$ Recently, it has also been shown that putative mammary stem cells in the mouse typically show the expression of high molecular cytokeratins and weak or almost absent expression of Ck 18 as well as lack of expression for ER. Furthermore, these cells were EGFR-positive and HER2-negative. ${ }^{55}$ Interestingly, identical results concerning cytokeratin expression patterns were obtained by Dontu et al, who also noted a high proliferation potential of $\mathrm{Ck} 5+, \mathrm{Ck} 8 / 18-$, ER- cells within primary mammospheres. ${ }^{56}$ The differentiation of these cells into differentiated glandular cells was paralleled by a complete phenotypic change of these cells into $\mathrm{Ck} 5-$, Ck 8/18+, ER+ 
cells, again in almost complete concordance to the mouse model. ${ }^{57}$ Moreover, in most of these experiments these cells seemed to depend on an intact EGF/EGFR system. ${ }^{54}$ Further characterisations also showed positivity for vimentin and P-cadherin and reduced expression of p21 and p27 in these progenitor/stem cells. ${ }^{58}$

The similarities of these protein expression patterns in physiological progenitor cells of the breast and the basal breast cancer subgroup are striking. As fig 2 shows, the present state of knowledge defines a spectrum of physiological cellular compartments within the female breast. The extreme ends of this spectrum (progenitor/stem cells and luminal cells) can easily be defined by a variety of proteins. In parallel, the distribution of these protein expression patterns is similar in the spectrum of invasive breast cancer.

This spectrum is not only defined by different protein expression patterns but also by the presence of distinct

A

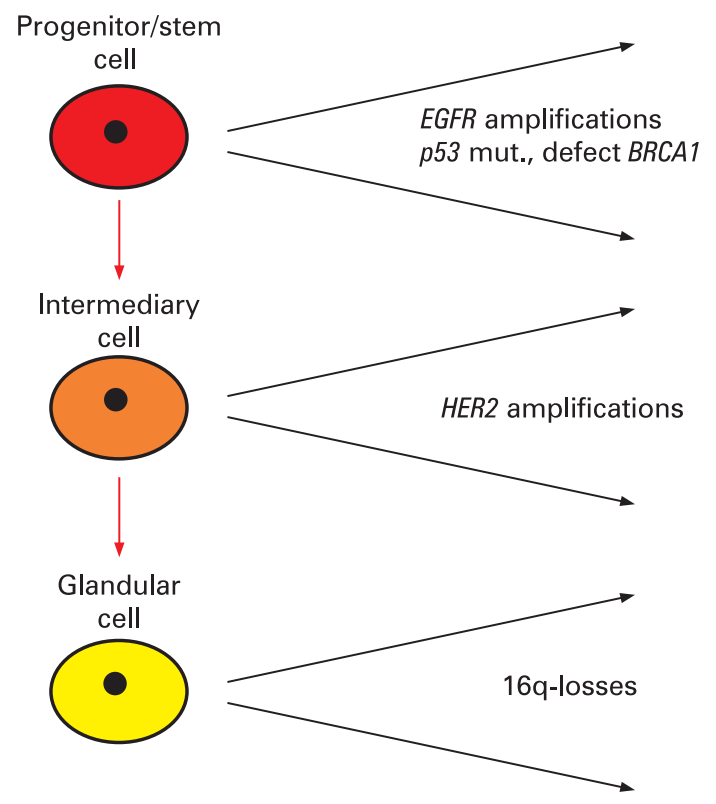

(Adeno)myoepithelial carcinoma

Metaplastic carcinoma

BRCA1-associated

carcinoma medullary carcinoma

Ductal invasive

"basal" carcinoma

Basoluminal carcinoma

Ductal invasive

grade 3 carcinoma

Ductal invasive

grade $1-3$ carcinoma

Tubular and

lobular invasive carcinoma

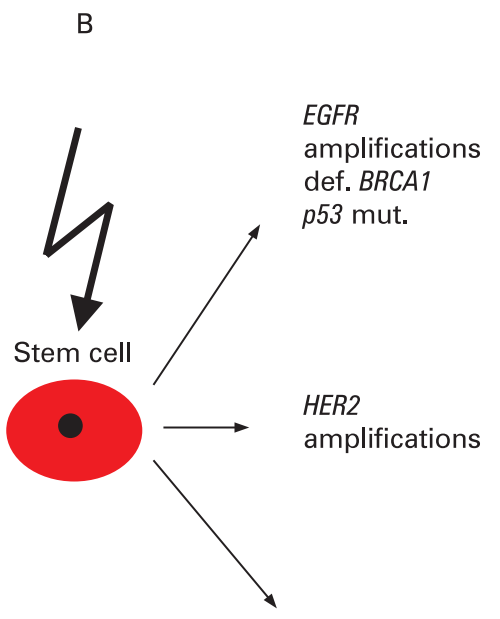

$16 q$-losses

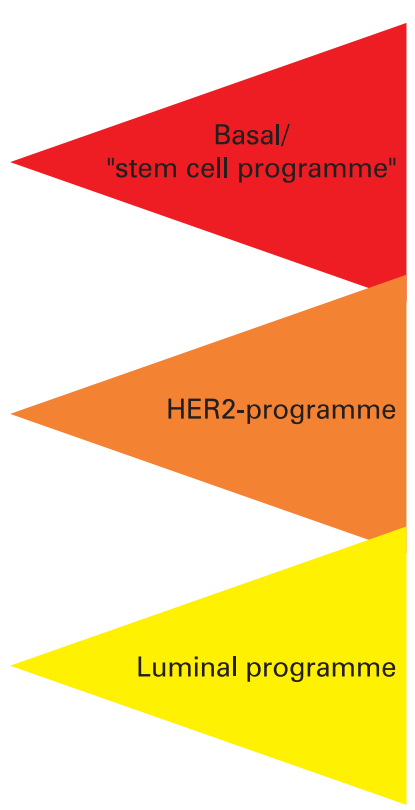

(Adeno)myoepithelial carcinoma

Metaplastic carcinoma

BRCA1-associated

carcinoma

medullary carcinoma

Ductal invasive

"basal" carcinoma

Basoluminal carcinoma

Ductal invasive

grade 3 carcinoma

Ductal invasive grade $1-3$ carcinoma

Tubular and lobular invasive carcinoma

Figure 3 Different putative histogenetic models of the relationship between different subgroups of invasive breast cancer and progenitor cells/stem cells. (A) "Linear cell of origin theory". The vastly overlapping expression profiles between physiological progenitor cells and invasive breast cancer supports the conclusion that the respective carcinoma subgroups originated in their respective physiological counterparts. Whereas $16 q$-losses are rare events in breast cancer types with expression of Ck 5, the incidence increases with lower tumour grade. In contrast, EGFR amplifications, p53mutations and defects/losses of BRCA1 are almost exclusively seen in high grade carcinomas that show Ck 5 expression. Also, HER2-amplifications are not seen in carcinomas with $\geqslant 50 \%$ Ck 5 positive cells. (B) "Stem cell hypothesis". Evidence is growing that physiological, organ-specific stem cells are the major target in the pathogenesis of different cancer entities, including breast cancer. As stem cells by definition are slowly proliferating, early progenitor cells or so called transit amplifying cells 1 st order with a high proliferation capacity are the major target cells. A multitude of genetic alterations can take place in these cells. The respective genetic alteration would, in consequence, start distinct cellular expression programmes, including the change of cytokeratin expression pattern, characterising distinct subgroups of invasive breast cancer. 
(cyto)genetic alteration patterns. Whereas basal carcinomas have been defined by the presence of EGFR-amplifications, ${ }^{29}$ loss of BRCA1 $1^{59}$ and/or p53-mutations, ${ }^{9}$ chromosomal 16q-losses were rare in these tumours. ${ }^{36}$ This was in contrast to ERpositive tumours, with $16 \mathrm{q}-$ losses $^{60}$ as a hallmark.

These associations suggest at least two explanations. Against the background of the above mentioned subsets of progenitor cells, it may be that distinct cytogenetic alterations can show their effect only in distinct precursor cells. 16q-losses in this regard may predominantly occur in more mature progenitor cells, whereas "basal" changes may arise in early, more stem cell-like, progenitor cells. In other words, the tumour would reflect or maintain cellular properties of its progenitor or more differentiated cell of origin (fig 3A). An alternative explanation, taking into account the ongoing discussion about organ-specific stem cells as target cells, ${ }^{61}$ would instead point towards direct changes in the stem cell itself and, as a result, protein expression patterns in the tumour that reflect specific genetic alterations in the progression from stem cell to tumour cell. This would then suggest that, for example, EGFR-amplifications or the loss of $B R C A 1^{62}$ would start a "basal" expression programme, whereas in contrast $16 \mathrm{q}$-losses would lead to the expression of luminal markers as shown in fig $3 \mathrm{~B}$ and recently shown by microarray analysis. ${ }^{37}$

Alternative theories speculate about a myoepithelial origin of these tumours, as many "basal" markers are also expressed by myoepithelial cells in vitro or in vivo. ${ }^{476}$ Another proposed origin of basal tumours has been deduced from morphological and immunohistochemical dedifferentiation, defined as "epithelial-mesenchymal transition" (EMT), with the expression of vimentin as a major morphological hallmark of EMT. ${ }^{64}$ Even though all above listed theories have their shortcomings, the EMT and myoepithelial theories are flawed by some pure histopathological observations. Ductal carcinoma in situ (DCIS) is accepted as the ultimate precursor of invasive breast cancer; it is seen in the majority of basal breast cancer cases. ${ }^{43}$ As long as no evidence exists that myoepithelial cells are the cells of origin of DCIS, the presence of DCIS, associated with the immunohistochemical staining pattern, including the expression of vimentin, ${ }^{35}$ suggests a glandular, non-myoepithelial origin of these tumours (excluding the myoepithelial carcinomas). Moreover, an association of benign, myoepithelial tumours with the most common basal breast cancers has not been described to date. More recently a subgroup of DCIS with expression of HMW-cytokeratins has been described, pointing to the existence of a real precursor lesion for basal breast cancer. ${ }^{65}{ }^{66}$ EMT as a general mechanism is also disputable, based on the fact that vimentin, considered the most reliable marker of EMT, is expressed in similar degrees in DCIS and the adjacent invasive carcinomas-pointing to a general characteristic of the respective, individual tumour.

However, most of these results are associative and a definite proof would require experiments targeting different subgroups of physiological progenitor cells as has been previously done. ${ }^{67} 68$ A mouse model of the basal breast cancer subgroup has been recently described. ${ }^{69}$ However, most studies focus on the basal, progenitor compartment as cellular targets in oncogenesis. Experiments targeting $\mathrm{Ck} 18+/ \mathrm{Ck} 5 / 14-$ cells have yet to be performed.

\section{CLINICAL CONSEQUENCES}

What are the current clinical consequences of our knowledge about basal breast cancers? As mentioned above, the initial overall prognostic significance of basal carcinoma is now discussed intensively. ${ }^{70}$ However, from a practical point of view it seems that the existing guidelines for the workup of a breast cancer specimen with the determination of the ER, PR and HER2-expression status provides a suboptimal definition of basal tumours. The recently introduced term "triple-negative breast cancer" (ER negative, PR negative, HER2 negative) roughly describes the majority of basal breast cancers; however, the overlap between basal and triple negative breast cancer is imperfect, with basal cancers comprising perhaps $60-90 \%$ of triple negative breast cancers, depending on whether they are defined immunohistochemically or by expression profiling; also, basal tumours may themselves be molecularly heterogeneous. ${ }^{49} 71$ The terms, although occasionally used interchangeably, should be considered distinct for research and clinical purposes as not all basal cancers are triple negative. Therefore, results from future studies focused on triple negative breast cancers will not provide a clear characterisation for all basal breast cancers. However, keeping these discrepancies in mind, preliminary studies on triple negative breast cancers showed that their locoregional relapse rate is identical to that of other molecular subgroups, suggesting that conservative surgical treatment options are still available to patients with basal tumours. $^{72}$ However, one has to be aware that the basal subgroup is more frequently detected in interval breast cancers compared to screening-detected breast cancers. ${ }^{73}$ In vitro studies suggested different mechanisms of chemoresistance in basal and luminal breast carcinomas, ${ }^{74}$ even though the relation between an increased sensitivity and a poorer outcome cannot yet be explained. ${ }^{75}$ It has also been hypothesised that platinum salts based therapy regimens might be of advantage in the treatment of basal breast cancer as they seem to interfere with the BRCA-1 pathway. ${ }^{76}$ However, currently no specific systemic therapy is recommended for the treatment of triple negative/basal breast cancers and only limited data is available to support the selection of appropriate treatment. ${ }^{77}$ Data about chemosensitivity in p53-mutated breast cancers is controversial. In a prospective study, a complete pathological response to primary chemotherapy was reported in $45 \%$ of basal breast cancers and $45 \%$ of HER2-positive breast cancers, but only $6 \%$ of luminal breast cancers. ${ }^{78}$ Current recommendations regarding adjuvant chemotherapy for this tumour type are in flux and an interdisciplinary approach for individualisation of patient care remains the best approach.

\section{Take-home messages}

- Basal breast carcinomas are characterised by specific morphological, immunohistochemical and genetic features. However, there is no accepted consensus about the definition of basal breast cancers based on immunohistochemistry.

- Basal breast cancers are usually ER, PR and HER2 negative. However they are not identical to the so-called triple negative breast cancers, since the overlap between both terms is not complete. Therefore ongoing clinical studies should incorporate these discrepancies in the interpretation of their results.

- Basal breast cancers share a similar protein expression pattern compared to physiological stem/progenitor cells in the breast. Further investigation of basal tumours should enable penetrating insights into the relationship between breast cancer cells and their putative progenitor cells or cell of origin, respectively. 
In conclusion, from lessons learned from hereditary breast cancer, an improved understanding of less common tumour types is mandatory to advance our general understanding of breast carcinogenesis and clinical treatment and to finally solve the breast cancer puzzle.

Competing interests: None declared.

\section{REFERENCES}

1. Fitzgibbons PL, Page DL, Weaver D, et al. Prognostic factors in breast cancer. College of American Pathologists Consensus Statement 1999. Arch Pathol Lab Med 2000;127:966-78.

2. Buerger H, Otterbach F, Simon R, et al. Comparative genomic hybridization of ductal carcinoma in situ of the breast-evidence of multiple genetic pathways. J Pathol 1999;187:396-402

3. Buerger H, Mommers E, Littmann R, et al. Ductal invasive G2 and G3 carcinomas of the breast are the end stages of at least two different lines of genetic evolution. J Pathol 2001;194:165-70.

4. Roylance R, Gorman P, Harris W, et al. Comparative genomic hybridization of breast tumours stratified by histological grade reveals new insights into the biological progression of breast cancer. Cancer Res 1999;59:1433-6.

5. van de Vijver MJ, He YD, van't Veer LJ, et al. A gene-expression signature as a predictor of survival in breast cancer. N Engl J Med 2002;347:1999-2009.

6. van't Veer L, Dai $H$, van de Vijver $M$, et al. Gene expression profiling predicts clinical outcome of breast cancer. Nature 2002;415:530-6.

7. Sorlie T, Perou C, Tibshirani R, et al. Gene expression patterns of breast carcinomas distinguish tumor subclasses with clinical implications. Proc Natl Acad Sci USA 2001;98:10869-74.

8. Perou C, Sorlie T, Eisen M, et al. Molecular portraits of human breast tumours. Nature 2000:406:747-52.

9. Sorlie T, Tibshirani R, Parker J, et al. Repeated observation of breast tumor subtypes in independent gene expression data sets. Proc Natl Acad Sci USA 2003:100:8418-23.

10. Chang HY, Nuyten DS, Sneddon JB, et al. Robustness, scalability, and integration of a wound-response gene expression signature in predicting breast cancer survival. Proc Natl Acad Sci USA 2005;102:3738-43.

11. Dairkee SH, Puett L, Hackett AJ. Expression of basal and luminal epithelium-specific keratins in normal, benign, and malignant breast tissue. J Natl Cancer Inst 1988;80:691-5.

12. Fan C, Oh DS, Wessels $L$, et al. Concordance among gene-expression-based predictors for breast cancer. N Engl J Med 2006;355:560-9.

13. Moll R, Franke WW, Schiller DL, et al. The catalog of human cytokeratins: patterns of expression in normal epithelia, tumors and cultured cells. Cell 1982;31:11-24.

14. Bocker W, Bier B, Freytag G, et al. An immunohistochemical study of the breast using antibodies to basal and luminal keratins, alpha-smooth muscle actin, vimentin, collagen IV and laminin. Part II: Epitheliosis and ductal carcinoma in situ. Virchows Arch A Pathol Anat Histopathol 1992;421:323-30.

15. Gusterson BA, Ross DT, Heath VJ, et al. Basal cytokeratins and their relationship to the cellular origin and functional classification of breast cancer. Breast Cancer Res 2005; 7:143-8.

16. Petersen $\mathbf{O W}$, Lind $\mathrm{NH}$, Gudjonsson $\mathrm{T}$, et al. The plasticity of human breast carcinoma cells is more than epithelial to mesenchymal conversion. Breast Cancer Res 2001;3:213-7.

17. Dairkee SH, Ljung BM, Smith $\mathrm{H}$, et al. Immunolocalization of a human basal epithelium specific keratin in benign and malignant breast disease. Breast Cancer Res Treat 1987;10:11-20.

18. Santini D, Ceccarelli C, Taffurelli M, et al. Differentiation pathways in primary invasive breast carcinoma as suggested by intermediate filament and biopathological marker expression. J Pathol 1996;179:386-91.

19. Carey LA, Perou CM, Livasy CA, et al. Race, breast cancer subtypes, and survival in the Carolina Breast Cancer Study. JAMA 2006;295:2492-502.

20. Wetzels RH, Kuijpers HJ, Lane EB, et al. Basal cell-specific and hyperproliferationrelated keratins in human breast cancer. Am J Pathol 1991;138:751-63.

21. Wetzels RH, Holland R, van HU, et al. Detection of basement membrane components and basal cell keratin 14 in noninvasive and invasive carcinomas of the breast. Am J Pathol 1989;134:571-9.

22. Tsuda H, Takarabe T, Hasegawa F, et al. Myoepithelial differentiation in high-grade invasive carcinoma with large central acellular zones. Hum Pathol 1999:30:1134-9.

23. Tsuda H, Takarabe T, Hasegawa F, et al. Large acellular zones indicating myoepithelial tumour differentiation in high-grade invasive ductal carcinomas as markers of predisposition to lung and brain metastasis. Am J Surg Pathol 2000;24:197-202.

24. Rakha E, Putti T, Abd El-Rehim D, et al. Morphological and immunophenotypic analysis of breast carcinomas with basal and myoepithelial differentiation. $J$ Pathol 2006;208:495-506.

25. Reis-Filho JS, Milanezi F, Steele D, et al. Metaplastic breast carcinomas are basallike tumours. Histopathology 2006;49:10-21.

26. Jacquemier J, Padovani $L$, Rabayrol $L$, et al. Typical medullary breast carcinomas have a basal/myoepithelial phenotype. J Pathol 2005;207:260-8.

27. Foulkes WD, Stefansson IM, Chappuis PO, et al. Germline BRCA1 mutations and a basal epithelial phenotype in breast cancer. J Natl Cancer Inst 2003:95:1482-5.
28. Abd El-Rehim DM, Ball G, Pinder SE, et al. High-throughput protein expression analysis using tissue microarray technology of a large well-characterised series identifies biologically distinct classes of breast cancer confirming recent cDNA expression analyses. Int J Cancer 2005:116:340-50.

29. Reis-Filho JS, Milanezi F, Carvalho S, et al. Metaplastic breast carcinomas exhibit EGFR, but not HER2, gene amplification and overexpression: immunohistochemical and chromogenic in situ hybridization analysis. Breast Cancer Res 2005;7:R1028-35.

30. Kersting C, Tidow N, Schmidt H, et al. Gene dosage PCR and fluorescence in situ hybridization reveal low frequency of EGFR amplifications despite protein overexpression in invasive breast carcinoma. Lab Invest 2004:84:582-7.

31. Sauter G, Simon R, Hillan K. Tissue microarrays in drug discovery. Nat Rev Drug Discov 2003:2:962-72.

32. Bertucci F, Finetti $P$, Cervera N, et al. Gene expression profiling shows medullary breast cancer is a subgroup of basal breast cancers. Cancer Res 2006;66:4636-44.

33. Eisinger $\mathbf{F}$, Jacquemier $\mathrm{J}$, Charpin $\mathrm{C}$, et al. Mutations at BRCA1: the medullary breast carcinoma revisited. Cancer Res 1998;58:1588-92.

34. Korsching E, Packeisen J, Agelopoulos K, et al. Cytogenetic alterations and cytokeratin expression patterns in breast cancer: integrating a new model of breast differentiation into cytogenetic pathways of breast carcinogenesis. Lab Invest 2002:82:1525-33.

35. Korsching $\mathbf{E}$, Packeisen J, Liedtke $\mathrm{C}$, et al. The origin of vimentin expression in invasive breast cancer: epithelial-mesenchymal transition, myoepithelial histogenesis or histogenesis from progenitor cells with bilinear differentiation potential? J Pathol 2005;206:451-7.

36. Zhao X, Li C, Paez JG, et al. An integrated view of copy number and allelic alterations in the cancer genome using single nucleotide polymorphism arrays. Cancer Res 2004;64:3060-71

37. Wennmalm K, Calza S, Ploner A, et al. Gene expression in $16 q$ is associated with survival and differs between Sorlie breast cancer subtypes. Genes Chromosomes Cancer 2007; 46:87-97.

38. Jones C, Ford E, Gillett C, et al. Molecular cytogenetic identification of subgroups of grade III invasive ductal breast carcinomas with different clinical outcomes. Clin Cancer Res 2004;10(18 Pt 1):5988-97.

39. Laakso M, Tanner M, Nilsson J, et al. Basoluminal carcinoma: a new biologically and prognostically distinct entity between basal and luminal breast cancer. Clin Cancer Res 2006;12(14 Pt 1):4185-91.

40. Jumppanen M, Gruvberger-Saal S, Kauraniemi $\mathrm{P}$, et al. Basal-like phenotype is not associated with patient survival in estrogen-receptor-negative breast cancers. Breast Cancer Res 2007:9:R16.

41. Jones C, Nonni AV, Fulford L, et al. CGH analysis of ductal carcinoma of the breast with basaloid/myoepithelial cell differentiation. Br J Cancer 2001;85:422-7.

42. Fulford LG, Reis-Filho JS, Ryder $\mathrm{K}$, et al. Basal-like grade III invasive ductal carcinoma of the breast: patterns of metastasis and long-term survival. Breast Cancer Res 2007:9:R4.

43. Fulford LG, Easton DF, Reis-Filho JS, et al. Specific morphological features predictive for the basal phenotype in grade 3 invasive ductal carcinoma of breast. Histopathology 2006:49:22-34

44. Livasy CA, Karaca G, Nanda R, et al. Phenotypic evaluation of the basal-like subtype of invasive breast carcinoma. Mod Pathol 2006;19:264-71.

45. Nielsen TO, Hsu FD, Jensen K, et al. Immunohistochemical and clinical characterization of the basal-like subtype of invasive breast carcinoma. Clin Cancer Res 2004;10:5367-74

46. Leibl S, Moinfar F. Metaplastic breast carcinomas are negative for Her-2 but frequently express EGFR (Her-1): potential relevance to adjuvant treatment with EGFR tyrosine kinase inhibitors? J Clin Pathol 2005;58:700-4.

47. Leibl S, Gogg-Kammerer M, Sommersacher A, et al. Metaplastic breast carcinomas: are they of myoepithelial differentiation? Immunohistochemical profile of the sarcomatoid subtype using novel myoepithelial markers. Am J Surg Pathol 2005:29:347-53.

48. Matos I, Dufloth R, Alvarenga M, et al. p63, cytokeratin 5, and P-cadherin: three molecular markers to distinguish basal phenotype in breast carcinomas. Virchows Arch 2005;447:688-94.

49. Kreike B, van KM, Horlings $\mathrm{H}$, et al. Gene expression profiling and histopathological characterization of triple-negative/basal-like breast carcinomas. Breast Cancer Res 2007;:9:R65.

50. Lakhani SR, Reis-Filho JS, Fulford L, et al. Prediction of BRCA1 status in patients with breast cancer using estrogen receptor and basal phenotype. Clin Cancer Res 2005; 11:5175-80.

51. Rakha EA, El-Sayed M, Green AR, et al. Breast carcinoma with basal differentiation: a proposal for pathology definition based on cytokeratin expression. Histopathology 2007:50:434-8

52. Jarasch ED, Nagle RB, Kaufmann M, et al. Differential diagnosis of benign epithelial proliferations and carcinomas of the breast using antibodies to cytokeratins. Hum Pathol 1988;19:276-89.

53. Pechoux C, Gudjonsson T, Ronnov-Jessen L, et al. Human mammary luminal epithelial cells contain progenitors to myoepithelial cells. Dev Biol 1999;206:88-99.

54. Deugnier MA, Faraldo MM, Janii B, et al. EGF controls the in vivo developmental potential of a mammary epithelial cell line possessing progenitor properties. J Cell Biol 2002;159:453-63.

55. Shackleton M, Vaillant F, Simpson KJ, et al. Generation of a functional mammary gland from a single stem cell. Nature 2006;439:84-8

56. Dontu G, Abdallah WM, Foley JM, et al. In vitro propagation and transcriptional profiling of human mammary stem/progenitor cells. Genes Dev 2003;17:1253-70. 
57. Asselin-Labat ML, Shackleton M, Stingl J, et al. Steroid hormone receptor status of mouse mammary stem cells. J Natl Cancer Inst 2006;98:1011-4.

58. Stingl J, Eirew P, Ricketson I, et al. Purification and unique properties of mammary epithelial stem cells. Nature 2006:439:993-7.

59. Turner N , Tutt A, Ashworth A. Hallmarks of 'BRCAness' in sporadic cancers. Nat Rev Cancer 2004;4:814-9.

60. Wang ZC, Lin M, Wei LJ, et al. Loss of heterozygosity and its correlation with expression profiles in subclasses of invasive breast cancers. Cancer Res 2004;64:64-71.

61. Reya T, Morrison SJ, Clarke MF, et al. Stem cells, cancer, and cancer stem cells. Nature 2001:414:105-11.

62. Turner NC, Reis-Filho JS, Russell AM, et al. BRCA1 dysfunction in sporadic basal-like breast cancer. Oncogene 2007;26:2126-32.

63. Jones C, Mackay A, Grigoriadis A, et al. Expression profiling of purified normal human luminal and myoepithelial breast cells: identification of novel prognostic markers for breast cancer. Cancer Res 2004:64:3037-45.

64. Tarin D, Thompson EW, Newgreen DF. The fallacy of epithelial mesenchymal transition in neoplasia. Cancer Res 2005;65:5996-6000.

65. Bryan BB, Schnitt SJ, Collins LC. Ductal carcinoma in situ with basal-like phenotype: a possible precursor to invasive basal-like breast cancer. Mod Pathol 2006;19:617-21.

66. Livasy CA, Perou CM, Karaca G, et al. Identification of a basal-like subtype of breast ductal carcinoma in situ. Hum Pathol 2007:38:197-204.

67. Elenbaas B, Spirio L, Koerner F, et al. Human breast cancer cells generated by oncogenic transformation of primary mammary epithelial cells. Genes Dev 2001;15:50-65.

68. Li Y, Welm B, Podsypanina K, et al. Evidence that transgenes encoding components of the Wnt signaling pathway preferentially induce mammary cancers from progenitor cells. Proc Natl Acad Sci USA 2003:100:15853-8.
69. McCarthy A, Savage K, Gabriel A, et al. A mouse model of basal-like breast carcinoma with metaplastic elements. J Pathol 2007:211:389-98.

70. Cleator S, Heller W, Coombes RC. Triple-negative breast cancer: therapeutic options. Lancet Oncol 2007:8:235-44.

71. Rakha EA, Tan DS, Foulkes WD, et al. Are triple negative tumours and basal-like breast cancer synonymous? Breast Cancer Res 2007;9:R80.

72. Haffty BG, Yang 0 , Reiss $\mathrm{M}$, et al. Locoregional relapse and distant metastasis in conservatively managed triple negative early-stage breast cancer. J Clin Oncol 2006;24:5652-7.

73. Collett K, Stefansson IM, Eide J, et al. A basal epithelial phenotype is more frequent in interval breast cancers compared with screen detected tumors. Cancer Epidemiol Biomarkers Prev 2005;14:1108-12.

74. Rouzier R, Perou CM, Symmans WF, et al. Breast cancer molecular subtypes respond differently to preoperative chemotherapy. Clin Cancer Res 2005;11:5678-85.

75. Carey LA, Dees EC, Sawyer L, et al. The triple negative paradox: primary tumor chemosensitivity of breast cancer subtypes. Clin Cancer Res 2007;13:2329-34.

76. Turner N, Tutt A, Ashworth A. Targeting the DNA repair defect of BRCA tumours. Curr Opin Pharmacol 2005:5:388-93.

77. Sorlie T, Perou CM, Fan C, et al. Gene expression profiles do not consistently predic the clinical treatment response in locally advanced breast cancer. Mol Cancer Ther 2006:5:2914-8

78. Urruticoechea A, Smith IE, Dowsett M. Proliferation marker Ki-67 in early breast cancer. J Clin Oncol 2005;23:7212-20.

79. van de RM, Perou CM, Tibshirani R, et al. Expression of cytokeratins 17 and 5 identifies a group of breast carcinomas with poor clinical outcome. Am J Pathol 2002;161:1991-6.

80. Baneriee S, Reis-Filho JS, Ashley S, et al. Basal-like breast carcinomas: clinical outcome and response to chemotherapy. J Clin Pathol 2006;59:729-35. 